1992

\title{
Religious Liberty in the Military: The First Amendment under "Friendly Fire"
}

Kenneth Lasson

University of Baltimore School of Law, klasson@ubalt.edu

Follow this and additional works at: http://scholarworks.law.ubalt.edu/all_fac

Part of the Civil Rights and Discrimination Commons, First Amendment Commons, Military, War, and Peace Commons, and the Religion Law Commons

\section{Recommended Citation}

Religious Liberty in the Military: The First Amendment under "Friendly Fire", 9 J. L. \& Religion 471 (1992)

This Article is brought to you for free and open access by the Faculty Scholarship at ScholarWorks@University of Baltimore School of Law. It has been accepted for inclusion in All Faculty Scholarship by an authorized administrator of ScholarWorks@University of Baltimore School of Law. For more information, please contact snolan@ubalt.edu. 


\title{
RELIGIOUS LIBERTY IN THE MILITARY: THE FIRST AMENDMENT UNDER "FRIENDLY FIRE"
}

\author{
Kenneth Lasson*
}

Though freedom of religion remains one of our most cherished values, it is still among the most controversial of constitutional rights. This is especially true in the context of military service. Even those who purposefully enlist in the armed forces, implicitly giving up certain liberties they freely enjoyed as civilians, would not relinquish their freedom of conscience. Yet the right to practice their religious beliefs, unfettered by arbitrary governmental restrictions, is regularly challenged.

Fortunately, however, most western cultures regard religious liberty as so fundamental that their military establishments routinely develop regulations to accommodate specific religious practices.

This principle was of particular import in the recent conflict in the Persian Gulf, during which the American government sought to limit the conduct of its military personnel so as not to offend the religious sensibilities of fundamentalist Arabs, specifically the host nation of Saudi Arabia. To what extent such political and strategic restrictions impinge upon basic constitutional principles is a question that has not yet been fully explored.

This article examines specific restrictions promulgated and practiced during the Persian Gulf War, provides a brief historical analysis of how the United States and other nations have traditionally accommodated the religious activities of their military personnel, and addresses the question of how far we can constitutionally limit the freeexercise rights of the people in the military in light of current Supreme Court jurisprudence.

\section{Operation Desert Shield}

When the United States sent a military force to Saudi Arabia in late summer of 1990 , it is unlikely that the governments of either country anticipated the sheer variety of religious tensions that would

* Professor of Law, University of Baltimore. The author thanks his research assistants, Lori Broser and Alisa Kobrinetz, for their help in preparation of this article. 
be roiled up by Operation Desert Storm-nor the constitutional questions encountered as a result.

Not only do the Saudis have strict moral codes pertaining to women, liquor, tobacco, dress, and the sanctity of various holy sites, but they strictly regulate the conduct, comings and goings of all non-Moslems as well. These concerns, in addition to the promulgation of political policies that are stridently skewed against America's only democratic ally in the region, Israel, have caused both the State Department and the Pentagon to walk increasingly fine lines to avoid both political and cultural conflicts.

Thus, for example, early on in the campaign, Jewish-American service members were given the "option" of receiving "non-denominational dogtags." This offer was followed with a pamphlet issued by The United States Central Command on sensitive topics to be "avoided or handled carefully"2_including "articles and stories showing U.S.-Israeli ties and friendship," "discussing the "Jewish lobby' and U.S. intelligence given to Israel," and "referring to the Arab blacklisting of U.S. companies that do business with Israel or the Arab boycotting of companies that have strong Zionist representation in executive positions." 3

Beyond the obviously defensible position that military personnel be afforded the opportunity to disguise their religious identities in the event they are captured by an enemy, in this case the official governmental overtures were based on a considerably more dubious policy: the official blind-eye approach toward Saudi Arabia's grossly discriminatory fundamentalism. Such diplomatic obsequiousness toward the oil-rich kingdom has been going on nearly a half-century, and in turn has served to endorse practices that are clearly anathema to free societies.

Regulating dress and drinking so as not to offend highly conservative allies is one thing, but repressing religious identity and observances is quite another. Besides the clear first amendment problems created by ordering service people not to discuss certain matters unrelated to specific military actions, American troops were asked to submerge the values of tolerance, pluralism and open-mindedness that have made the United States a unique democratic society. ${ }^{4}$

1. Letter from Senator Patrick Moynihan to Secretary of Defense Dick Cheney, dated August 22, 1990, in author's files.

2. Associated Press wire story, October 28, 1990.

3. Id.

4. Id. 
Prior to 1990, Jews and Blacks were purposefully denied assignment to Saudi Arabia. But that situation had to change, of necessity, when American forces were brought in in large numbers-ultimately over 500,000 troops from all the services.

From the earliest months of American military deployment in the Persian Gulf, various regulations, directives, orders, and advisories sought to limit religious practices and expressions. Military chaplains, for example, were ordered to remove insignia showing their religion, and told to call themselves "morale officers." Also, chaplains were prohibited from being interviewed by the media, which in turn was forbidden to film any religious worship services. This was even on bases far away from Saudi citizens or military personnel, and caused a major negative response among the hundreds of chaplains deployed in the Gulf. ${ }^{5}$

Although the Pentagon officially denies there was any substantial restriction on religious freedom of soldiers and sailors, there is enough anecdotal material to cause concern. The press was instrumental in uncovering a number of incidents, long before the official regulations were acknowledged by the military. Thus, it became known that chaplains were told not to wear crosses when away from the troops, or to use terms like "mass" or "holy communion." Some "morale" services had to be held in secret. And certain Christmas carols or hymns were off limits (chaplains were told to substitute "Jingle Bells" for "Oh, Come All Ye Faithful"). President Bush himself, although he declared that we were there "to protect our Arab friends and the American way of life," changed a planned visit to the front from Christmas to Thanksgiving so as not to offend the Saudis. ${ }^{6}$

According to one Jewish chaplain, the restrictions on Jews were more onerous than those placed upon Christians. There was an inadequate number of Jewish chaplains to cover the estimated 2500 Jewish military personnel. It was difficult to obtain copies of the Old Testament and kosher food. Although after awhile Christian services on bases were posted, Jewish services were not-this, by military order. ${ }^{7}$

5. The total number of American military chaplains in the Persian Gulf was 835, of whom eighteen were women and seven were Jewish.

Interestingly enough, there were about 700 Muslim U.S. troops but no Muslim chaplains. One problem that arose on several occasions was how to perform marriages on American bases, because non-Muslim marriages are prohibited on Saudi soil. Another problem was how to handle Muslim prisoners of war. The official policies regarding religious practices were promulgated by way of various orders and directives (copies in author's files).

6. 137 CoNG. Rec. E2966-67 (daily ed. Aug. 15, 1991)(statement by Rep. Gilman).

7. Telephone interview with Jewish chaplain, 10/2/91 (author's files). 
Most if not all of these orders and practices may have been the result of an over-reaction by military commanders and the State Department to a misperceived sense of the need to defer to Arab fundamentalist sentiments. It is fairly clear now that the restrictions placed on the troops were much more the product of Americans than Saudis. ${ }^{8}$ For the most part it was friendly fire, and entirely avoidable.

The senior chaplain in the Persian Gulf theater stated that American commanders may have floundered at first, but that the Saudis were not very concerned about what religious activities were carried out on the bases; in fact, he said, by war's end the religious program in effect was the best he had ever seen. ${ }^{9}$ (The only horror story about the Saudis themselves was that of an American who reported he had been severely reprimanded by a Saudi general for using asterisks in a report he had done, because they looked too much like the six-pointed Stars of David. $)^{10}$

In fact there was no "status of forces" agreement in Saudi Arabia, the way there is in Germany or other places where Americans are present in any great numbers. There were only letters of understanding as to what practices would be accepted and which would be frowned upon. ${ }^{11}$

In the end, the chaplains emerged as heroes. For them it was no small irony that the rigidly puritanical cultural environment in Saudi Arabia allowed for greater spiritual opportunities-an anomaly that at the beginning was lost on American policy-makers and commanders in the field. ${ }^{12}$

By war's end, the senior chaplain in the Gulf could say that the religious program ultimately in effect was the best he had ever seen. From interviews with a number of military personnel who served in the Gulf, particularly members of the chaplaincy, a clear picture begins to emerge. Despite the regulations promulgated from abovefrom the State Department, the Secretary of Defense, and others in positions of influence-military personnel from all the services freely engaged in religious practices. Directives were widely disregarded. Chaplains refused to call themselves "morale officers." Services were held for all denominations, on all holidays. Kosher food, while diffi-

\footnotetext{
8. Telephone interview with senior chaplain in Persian Gulf, 10/2/91 (author's files).

9. Id. On the other hand, there were indications that the Saudis were "very concerned" as to how U.S. troops would conduct themselves during holidays. Id.

10. Cong. Rec., supra note 6.

11. (Data in author's files.).

12. Telephone interview with senior chaplain in Persian Gulf, 10/2/91 (author's files.)
} 
cult to obtain on military bases, (though kosher MREs are supposedly being discussed at present), was available in Riyadh —as was a Torah scroll flown in on a military transport from Frankfurt, West Germany. ${ }^{13}$

So whatever restrictions there were seem to have been honored more in the breach than anywhere else.

\section{Free Exercise vs. Military Necessity}

Americans abide by the principle that the liberty to choose one's faith and practice it without inhibition is essential to the function of a free society. Thus, the first amendment to the United States Constitution provides that, "Congress shall make no law respecting the establishment of religion, or prohibiting the free exercise thereof . . ." 14

The free exercise clause has served to limit the degree to which government may interfere with the pursuit and practice of religion. ${ }^{15}$ There is controversy, however, as to the degree to which the Constitution permits the military the power to grant service members less protection of their fundamental rights than they would be accorded in civilian society. In recent years a number of cases have enunciated the principle that the military can be classified as distinct from civilian society, ${ }^{16}$ thereby justifying military interference and restriction of a service member's free exercise of religion.

The latest challenges to the free exercise clause have come in the wake of the Supreme Court's 1990 opinion in Employment Division, Oregon Department of Human Resources v. Smith. ${ }^{17}$ Prior to Smith the Court had generally applied a "strict scrutiny" test in religion cases-that is, for any law restricting a religious practice to pass constitutional muster, the government had to show both that the legislation was needed to satisfy a "compelling public interest" and that no less burdensome course of action was feasible. Because the strict scrutiny standard is a difficult one for the state to meet, over the years various religious practices have been exempted from otherwise applicable statutes and regulations.

In Smith, however, a sharply divided Supreme Court discarded

13. Jewish personnel also celebrated Passover, but to do so were moved off of Saudi soil and onto the Cunard Princess. (Data in author's files.).

14. U.S. Const., Amend. I.

15. See, e.g., Sherbert v. Verner, 374 U.S. 398, 402-03 (1963).

16. See, e.g., Parker v. Levy, 417 U.S. 733, 743-44 (1974) (military traditionally viewed by Court as "specialized society); see generally Hirschorn, The Separate Community: Military Uniqueness and Servicemember's Constitutional Rights, 62 N.C.L.REV. 177, 177-207 (1984).

17. 494 U.S. 872. 
the strict scrutiny test in favor of one that would make constitutional a "valid and neutral law of general applicability."18 The Court held that a state could enact any statute-even if it happens to restrict a religious practice-so long as it does not target a particular religion and is uniformly applied to all citizens. Greater protection of free exercise, said Justice Scalia in Smith, must be sought in the political process and not through the courts-even though he recognized that "the political process will place at a relative disadvantage those religious practices that are not widely engaged in."19

Justice O'Connor, one of four in strong dissent, characterized Scalia's opinion as "dramatically [departing] from well-settled First Amendment jurisprudence . . . unnecessary to resolve the question presented, and . . . incompatible with our Nation's fundamental commitment to individual religious liberty."20

More particularly, service members have challenged the constitutionality of military regulations as violative of their first amendment right to the free exercise of religion. Supreme Court jurisprudence is somewhat less than clear as to the degree to which civilians and military personnel are afforded the same constitutional rights. The Court has held that "our citizens in uniforms may not be stripped of basic rights simply because they have doffed their civilian clothes." 21 However, the Constitution grants plenary power to Congress "to raise and support Armies," "to provide and maintain a Navy," and "to make Rules for the Government and Regulation of the land and naval Forces." 22 Thus, it is patent that the Framers intended to give complete control to the legislative branch over the military establishment, including regulations and procedures. ${ }^{23}$ Consequently, the Supreme Court has traditionally deferred to professional military judgment regarding military regulations.

Not all burdens on religion are unconstitutional. ${ }^{24}$ For example, the Court has upheld state child labor laws that were used to prohibit the sale of religious literature by children who were Jehovah wit-

18. Id. at 879 .

19. Id. at 890 .

20. Id. at 891 .

21. Chappel v. Wallace, 462 U.S. 296, 304 (1983)(quoting Warren, The Bill of Rights and the Military, 37 N.Y.U.L. REv. 181, 188 (1962).

22. U.S. Const. art. I.

23. See, e.g., Solorio v. United States, 483 U.S. 435 (1987); Chappel, 462 U.S. at 301; and Houston v. Moore, 18 U.S. 1 (1820).

24. United States v. Lee, 455 U.S. 252, 257 (1982); Reynolds v. United States, 98 U.S. 145 (1878). 
nesses, ${ }^{25}$ and a federal statute prohibiting the practice of polygamy as applied to Mormons. ${ }^{26}$ In neither of these cases, however, did the Court set judicial standards as to when certain religious conduct could be regulated. ${ }^{27}$

It was not until the landmark case of Sherbert $v$. Verner ${ }^{28}$ that the Supreme Court offered a formula to guide future courts in deciding when the government has the right to interfere. In Sherbert, the Court announced the standard that the state must accommodate religious practice unless it can assert a compelling interest that cannot be furthered through other, less restrictive means. ${ }^{29}$ The case involved the denial of unemployment benefits to a Seventh-Day Adventist who refused to accept suitable work on her Sabbath. Based on the "strict scrutiny" standard, the Court held that it was unconstitutional for a state to deny the benefits since the denial violated her first amendment right to free exercise of religion absent a compelling state interest. ${ }^{30}$

Subsequent to Smith, numerous decisions by various lower state and federal courts have felt constrained by that holding. In the main, free exercise claims challenging both civil and criminal statutes have been markedly unsuccessful.

For example, federal courts of appeal have upheld laws which require blood transfusions, ${ }^{31}$ autopsies, ${ }^{32}$ and church contributions to a public social insurance plan $^{33}$-none of which would likely have survived the prior strict scrutiny test.

Similarly, lower federal courts have found various restrictions on religion not to violate the Constitution, including the public accommodations title of the Civil Rights Act of 1964 (construed to require the Boy Scouts of America to admit into membership persons who are unwilling to profess a belief in God); ${ }^{34}$ a charitable-solicitations ordinance that imposed disclosure and recordkeeping requirements on most charitable organizations soliciting funds within the city (al-

25. Prince v. Massachusetts, 321 U.S. 158 (1944).

26. Reynolds, 98 U.S. 145.

27. Folk, Military Appearance Requirements and Free Exercise of Religion, 98 MIL. L. REV. 53, 64 (1983).

28. 374 U.S. 398 (1963).

29. Id. at 406-07.

30. Id. at 403.

31. Munn v. Algee, 924 F.2d 568 (5th Cir. 1991).

32. Montgomery v. County of Clinton, Michigan, 743 F. Supp. 1253 (W.D. Mich. 1990).

33. South Ridge Baptist Church v. Industrial Comm'n of Ohio, 911 F.2d 1203 (6th Cir. 1990).

34. Welsh v. Boy Scouts of America, 742 F.Supp. 1413 (N.D. Ill. 1990). 
lowing no exception for religious organizations); ${ }^{35}$ and the government's covert surveillance of the worship services and other activities of churches involved in the sanctuary movement. ${ }^{36}$

State court decisions have been to the same effect. Pursuant to Smith these courts have rejected free exercise claims made by Christian Scientist parents; ${ }^{37}$ by a church subjected to a state consumer-use tax on items it purchased from out-of-state suppliers; ${ }^{38}$ by homeowners whose erection of three crosses in their front yard was held to violate the setback requirements of the city's zoning ordinance; ${ }^{39}$ and by a church that refused to obtain a state license for its child-care center because the licensing requirements would have prohibited it from disciplining children by spanking in accord with its understanding of the Bible. ${ }^{40}$

In four instances to date, courts have resorted to their state constitutions in order to get around the dictate of Smith. In Minnesota v. Hershberger ${ }^{41}$ the state supreme court ruled that the Amish had a free-exercise right under the Minnesota constitution to be exempted from a state law requiring slow-moving vehicles to display fluorescent orange emblems. In State by Cooper v. French ${ }^{42}$ the same court again relied on the state constitution to uphold a landlord's religiously based refusal to rent a house to a woman who planned to cohabit with her fiance-contrasting that conclusion with what is said was the lesser level of protection afforded religious exercise under Smith. And in Matter of Welfare of T.K. and W.K..$^{43}$ an appellate court (again in Minnesota) held the religious conscience provision of the state constitution to be violated by removal of two children from a home because of the parents' religiously-based refusal to allow the state to check the quality of their home schooling by way of a standardized test. Although the court found the state's interest in education to be compelling, it held removal of the children from the home not to be the least restrictive alternative available to the state to ensure the educational quality of their home schooling. Finally, in Donahue v. Fair

35. Church of Scientology v. City of Clearwater, 756 F.Supp. 1498 (M.D. Fla. 1991).

36. Presbyterian Church (U.S.A.) v. United States, 752 F.Supp. 1505 (D. Ariz. 1990).

37. Hermanson v. Florida, 570 So.2d 322 (Fla. App. 2d dist. 1990).

38. Hope Evangelical Lutheran Church v. Iowa Department of Revenue and Finance, 463 N.W.2d 76 (lowa 1990).

39. Elsaesser v. City of Hamilton Board of Zoning Appeals, 573 N.E.2d 733 (1990).

40. Health Services Division, Health \& Environment Department of New Mexico v. Temple Baptist Church, 814 P.2d 130 (N.M. App. 1991).

41. 462 N.W.2d 393 (Minn. 1990).

42. 460 N.W.2d 2 (Minn. 1990).

43. 475 N.W.2d 88 (Minn.App. 1991). 
Employment and Housing Commission, ${ }^{44}$ a California appellate court held a landlord who refused to rent to an unmarried cohabiting couple to be constitutionally exempt under the California constitution from a statute prohibiting discrimination on the basis of marital status. The court, using a strict scrutiny analysis, found the state's interest in protecting unmarried cohabiting couples not to be a "paramount and compelling State interest," but the burden on the respondents' practice of their religion was "substantial."45

In sum, state and lower federal court application of the principle of non-exemption stated in Smith has resulted in the denial of most free exercise claims, except where the claim has been adjudicated under a state constitution.

In a 1967 case, United States v. Robel, ${ }^{46}$ the Supreme Court gave signs of dissatisfaction with this balancing of the competing interests of government and individuals in first amendment decisions. Robel dealt with a congressional statute designed to safeguard the national defense under its constitutional war powers. The Court refused to "balance" the government's interests with the individuals' right of association. The Court said the question was not what interest "outweighed" the other, but instead the emphasis was on how to avoid the conflict. ${ }^{47}$

This departure from balancing individual rights and government interests continued in Rostker v. Goldberg. ${ }^{48}$ There the Supreme Court considered the appropriate level of scrutiny by which to review a congressional decision excluding women from draft registration. The competing interests were the constitutional authority granted Congress to raise and regulate armies and navies against fifth amendment due process prohibition of gender-based discrimination. ${ }^{49}$ As in Robel, the Court determined that the interests could not be balanced against one other; the real test became how each interest could be accommodated.

\section{A. Military Necessity}

The general confusion as to which level of scrutiny should be

44. 2 Cal. Rptr.2d 32 (Ct. App. 2d Dist. 1991).

45. Id. at 46 .

46. 389 U.S. 258.

47. Id. at 268 .

48. 453 U.S. 57 (1981).

49. Zezula, Religious Accommodation in the Military, THE ARMY LAWYER, Jan. 1987, at 5. 
applied has seeped into the military context, where it has been further compounded by the doctrine of "military necessity."

The military has been given the status of a "separate community." 50 Because of the significance of military goals, the courts have upheld challenges to military actions which might have been unconstitutional in the civilian context. ${ }^{51}$ Under the doctrine of military necessity, first enunciated in Orloff v. Willoughby, ${ }^{52}$ the services can implement their own rules and regulations beyond the presence of judicial review. ${ }^{53}$ As former Supreme Court Chief Justice Warren observed in support of the so-called Orloff rule:

So far as the relationship of the military to its own personnel is concerned, the basic attitude of the Court has been that the latter's jurisdiction is most limited .... This "hands off" attitude has strong historical support, of course ... it is indisputable that the tradition of our country, from the time of the revolution until now, has supported the military establishment's broad power to deal with its own personnel. The most obvious reason is that Courts are ill-equipped to determine the impact upon discipline that any particular intrusion upon military authority might have. ${ }^{54}$

In 1974, twenty-one years after Orloff, came Parker v. Levy. ${ }^{53}$ The case involved statements designed to promote disloyalty and disaffection among troops destined for Vietnam. The Court noted that "while members of the military are not excluded from the protection granted by the First Amendment, the different character of the military community and of the military mission require a different application of these protections." Parker presented a much different analysis for a first amendment challenge then the Court would have used in a civilian context.

In 1980, the Supreme Court decided Brown v. Glines ${ }^{57}$ and Navy v. Huff. ${ }^{58}$ Glines challenged regulations requiring service members to obtain prior approval before circulating petitions on Air Force bases. In a civilian society such prior restraint would clearly violate the first amendment, yet the Court upheld the regulations, again stating that the military's role is one of a specialized and separate society and that

50. See Orloff v. Willoughby, 345 U.S. 83, 94 (1953).

51. Id. at 94 .

52. 344 U.S. 873 (1952).

53. Id.

54. Warren, supra note 21 , at $\mathbf{1 8 6 - 8 7}$.

55. 417 U.S. 733 (1974).

56. Id. at 758 .

57. 444 U.S. 348 (1980).

58. 444 U.S. 453 (1980). 
there is a strong need for loyalty, discipline, and morale to perform the mission. ${ }^{59} \mathrm{Huff}$ also involved obtaining approval from base commanders before circulating petitions; the Court again held that the regulation in question protected the interest in maintaining respect for duty and discipline vital to military effectiveness. ${ }^{60}$

The Court went even further in a 1983 case, Chappell v. Wallace. ${ }^{61}$ It held that enlisted armed forces personnel cannot maintain suits to recover damages from superior officers, when the enlisted personnel sustain alleged injuries in the course of military service as a result of constitutional violations. Therefore, service members were not only denied certain remedies for constitutional violations, but they could not even recover for any injuries sustained as a result.

This line of cases suggests that if the military wants to bypass the first amendment, all that is required is an assertion of "military necessity."62 There is no requirement to prove that granting a first amendment claim might have a detrimental effect on the military order. ${ }^{63}$

Should the military adopt a strict-scrutiny standard and require proof that a regulation pursues a compelling interest with least restrictive means, or a flat rule that automatically accommodates all religious needs of service members, or simply proceed on a case-bycase basis?

To adopt the strict-scrutiny standard would be to forego a long line of cases recognizing that the military is a separate and distinct society where a different application of constitutional protections is required. Further, the courts would become directly involved in reviewing these cases, and would be interfering in what should be the military's own role in performing its duties.

Similarly, the military could not adopt a rigid rule which would allow every religious practice to be accommodated. There is a need for loyalty, cohesion and discipline. To adopt such a standard would not only be inefficient and costly, but would individualize service members to such an extent as to undermine the military principle of uniformity. The best solution would be to separate the various requests for religious accommodation into categories and to come up with guidelines that can be used on a case-by-case basis. For instance,

59. 444 U.S. at 353 .

60. 444 U.S. at 458.

61. 462 U.S. 296 (1983).

62. Wechsler, Goldman v. Weinberger: Circumscribing the First Amendment Rights of Military Personnel, 30 ARIZ. L. REV. 349, 354 (1988).

63. Id. 
specific regulations should be passed and implemented regarding religious apparel, time-off for holidays and religious service, dietary restrictions, and medical treatment.

\section{B. Conscientious Objection}

The history of conscientious objector claims provides another basis for analyzing religious-based exemptions from military regulations. Colonial law generally exempted from compulsory military service anyone who objected to participation as a matter of conscience. ${ }^{64}$ In 1789, James Madison proposed to include free exercise of conscience in the first amendment. ${ }^{65}$ This idea was approved by the House of Representatives, but was deleted in the Senate without any record of an explanation. ${ }^{66}$

In 1863 , however, when Congress enacted the first draft law, ${ }^{67}$ no exemptions were provided for conscientious objectors. As a result of pressures from various religious sects, Congress later granted an exemption from combatant duty to those who were "conscientiously opposed to bearing arms, and who are prohibited from doing so by the rules and articles of faith of their religious denominations."68

The Selective Draft Act of $1917^{69}$ exempted persons from combatant service if they belonged to "any well-recognized religious sect or organization ... whose existing creed or principles forbid its members to participate in war of any form and whose religious convictions are against war or participation therein."70 However, this exemption applied only to combatant service-not military service in general.

In the Selective Draft Law Cases, ${ }^{71}$ the Court rejected both establishment and free-exercise clause challenges to conscientious objector exemptions in the Draft Act of 1917.

It was not until World War II that the Supreme Court first considered whether there was a first amendment requirement to exempt conscientious objectors from military service. ${ }^{72}$ Although the Court had explicitly held that there was no constitutional right to conscien-

64. N. Wherry, Conscientious Objection, Special Monograph No. 11, U.S. SeLeCTIVE SERVICE SYSTEM, ch. 3., at 29 (1950).

65. J. Swomley, Religious Liberty aNd the Secular State 90-91 (1987).

66. Id. at 91 .

67. Act of March 3, 1863, ch. 75, § 2, 12 Stat. 731 (1863).

68. Act of February 24, 1864, ch. 13, $\S 17,13$ Stat. 6, 9 (1864).

69. Act of May 18, 1917, ch. 15, $\S 4,40$ Stat. 76 (1917).

70. Id. at $\S 4,40$ Stat. at 78 .

71. 245 U.S. 366, 389-90 (1918).

72. See Folk, supra note 27 , at 58. 
tious objection, Congress provided an exemption from induction to combat for conscientious objectors if their opposition to participation in any war was based upon "religious training and belief." 73 Those who were granted the exemption were allowed as an alternative to engage in other duties under civilian control as an alternative. ${ }^{74}$

In Gillette v. United States, ${ }^{75}$ the Court held that the free exercise clause of the first amendment does not require exemption from military service of those conscientiously opposed to participation in particular wars. It was sufficient that the government's interests related directly to the burdens its regulations imposed on free exercise rights. ${ }^{76}$ In Johnson v. Robison, ${ }^{77}$ a statute that denied veterans' education benefits to conscientious objectors who performed alternate service was found not to violate the objectors' right to free exercise of religion. In both cases the Court indicated that it will require the government to show only a substantial interest rather than the compelling interest required by Sherbert. ${ }^{78}$ Thus, it would appear that Congress's constitutional power to raise and support armies is a sufficiently substantial interest.

\section{Current Practice, Cases and Controversies}

Accommodation of religious practices in the military services is currently governed by Department of Defense Directive Number 1300.17, issued February 3, 1988. In principle, all requests for indulgence of religious practices should be approved by commanders when such accommodation "will not have an adverse impact on military readiness, unit cohesion, standards, or discipline."79

The directive lists various goals in implementation of the policy. In pertinent part they are as follows:

a. Worship services, holy days, and Sabbath observance should be accommodated, except when precluded by military necessity.

b. The Military Departments should include religious belief as one factor for consideration when granting separate rations, and permit commanders to authorize individuals to provide their own

73. Act of September 16, 1940, ch. 720, § 5, 54 Stat. 885, 889 (1940).

74. Folk, supra note 27 , at 60 .

75. 401 U.S. 437 (1971).

76. Id. at 460 .

77. 415 U.S. 361 (1974).

78. 374 U.S. 398 (1963). See supra notes $27-29$ and accompanying text.

79. Department of Defense Directive Number 1300.17, at $\S$ C (February 3, 1988). 
supplemental food rations in a field or "at sea" environment to accommodate their religious beliefs.

c. The Military Departments should consider religious beliefs as a factor for waiver of immunizations, subject to medical risks to the unit and military requirements, such as alert status and deployment potential.

d. The Military Departments should include relevant materials on religious traditions, practices, and policies in the curricula for command, judge advocate, chaplain, and similar courses and orientations.

e. The Military Departments should develop a statement advising of DoD policy on individual religious practices and military requirements to applicants for commissioning, enlistment, and reenlistment. $^{80}$

Finally, the policy provides for the wearing of religious apparel both visible and nonvisible. The latter may be worn with the uniform, provided that it does not interfere with the performance of the service member's military duties or with the proper wearing of any authorized article of the uniform. ${ }^{81}$ Visible items may also be worn, "except under circumstances in which an item is not neat and conservative or its wearing shall interfere with the performance of the member's military duties." 82

\section{A. Appearance Standards}

Military forces have long required uniformity of dress and appearance as part of their practice of establishing and enforcing military discipline. Goldman v. Weinberger ${ }^{83}$ is the most prominent recent case. Prior to Goldman, three courts explored the extent to which military uniform regulations infringe on the free-exercise rights of service members. In Geller $v$. Secretary of Defense, ${ }^{84}$ the United States District Court for the District of Columbia ordered the Air Force to exempt an orthodox Jewish chaplain from a grooming regulation which prohibited the wearing of a beard. The court neither scrutinized the regulation nor applied the military-necessity doctrine. Instead, it referred to the chaplain's commendable service record and his status as a rabbi-a position where a beard is considered properand concluded that the specific circumstances required an exception

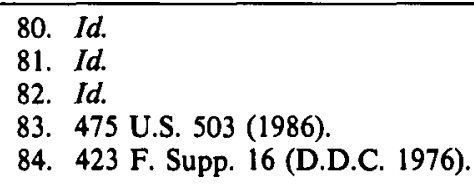


to be made for the "no-beard regulation." The court also determined that it was unnecessary to decide between judging the claim on a mere rationality test or Sherbert's compelling-interest test. ${ }^{85}$ The Air Force's interest in discipline, military image and neatness was not sufficient, under either test, to justify the application of the regulation because of the unique circumstances of the rabbi's case. ${ }^{86}$

Two years later, the Ninth Circuit decided Sherwood v. Brown, ${ }^{87}$ which became the first instance in which a court applied a strict scrutiny test to a claim to exemption from military appearance standards for religious reasons. The Sherwood court considered whether a United States Navy dress regulation that prohibited a Sikh sailor from wearing a turban violated his first amendment right to free exercise of religion. Because the turban prevented the sailor from wearing a protective helmet, said the court, the Navy could assert its interest in the safety of the crew members who depended on him; the court reasoned that the regulation met the compelling-interest test for restricting the free exercise of religion. ${ }^{88}$

More recently, in Bitterman v. Secretary of Defense, ${ }^{89}$ the question of whether strict scrutiny should be applied once again came to the fore. Bitterman, an orthodox Jew, sought to be exempted from Air Force regulations which prevented him from wearing a yarmulke (skullcap) while in uniform, under the free exercise clause. ${ }^{90}$ The court followed the standard adopted in Parker and Glines and concluded that its review must include substantial deference to military judgments. ${ }^{91}$ It found that a compelling interest existed in applying Air Force uniform regulations to Sergeant Bitterman's wearing of a yarmulke, and that departures from these standards of uniformity would adversely affect teamwork, counteract pride, and inhibit efforts to maintain morale and discipline. ${ }^{92}$

Thus, once again the cases in lower courts yield conflicting results. Unfortunately, Goldman did little to clear up the confusion. The Supreme Court was called upon to consider the constitutionality of an Air Force regulation which prohibited an orthodox Jewish ser-

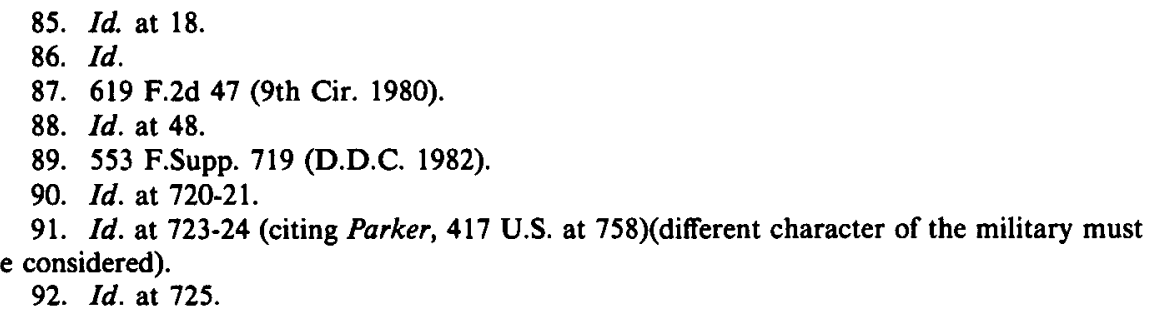


viceman from wearing a yarmulke while on duty. By a narrow (fivefour) majority, the Court held that the Air Force regulation did not infringe upon the serviceman's first amendment "free exercise" rights. Rejecting the argument that the strict-scrutiny standard (enunciated in Sherbert) should be applied to Goldman's free-exercise claim, Justice Rehnquist's opinion relied heavily on the military-necessity doctrine. "Within the military community there is simply not the same (individual) autonomy as there is in the larger civilian community." 93 Furthermore, said Rehnquist, military regulations are to be reviewed with "far more" deference than similar laws for civilian society. ${ }^{94}$

The majority of the Court concluded that "the desirability of dress regulations in the military is decided by the appropriate military officials, and they are under no constitutional mandate to abandon their considered professional judgment," and as long as the military "reasonably and evenhandedly" regulated dress requirements, the Court would allow the regulation to stand. ${ }^{95}$ Justice Stevens, concurring, agreed that military regulatory judgments should be accorded extraordinary deference. He feared that an exception for Orthodox Jews wearing yarmulkes would force the Air Force to draw distinctions among religions - something the Air Force had "no business" doing. ${ }^{96}$

The dissenting opinions in Goldman illustrate just how much the military was in need of guidelines in the area of religious apparel. Justice Blackmun felt that the precedents requiring a standard of strict scrutiny controlled Dr. Goldman's claim, regardless of the fact that they were not decided in military context. ${ }^{97}$ Justice Brennan declared that Dr. Goldman was denied a meaningful constitutional review because the Court applied a "subrational" level of scrutiny to the military regulation. ${ }^{98}$ And Justice O'Connor, joined by Justice Marshall, argued that the judiciary should apply the same free exercise test in civilian and military contexts. ${ }^{99}$ Her two-pronged test would require the government to demonstrate that the interest it asserts against a religiously based claim "is of unusual importance" and that granting an exemption would "do substantial harm to the especially important

93. 475 U.S. at 507.

94. Id.

95. Id. at $509-10$.

96. Id. at 513 (Stevens, J., concurring).

97. Id. at 525-26 (Blackmun, J., dissenting).

98. Id. at 515 (Brennan, J., dissenting).

99. Id. at 530 (O'Connor, J., dissenting). 
government interest." 100

Goldman has become the object of considerable criticism, the greatest objection being its extreme deference to the military. Immediately following the Circuit Court's decision in Goldman, Congress ordered the Secretary of Defense to form a study group "to examine ways to minimize the potential conflict between the interests of members of the armed forces in abiding by their religious tenets and the military interest in maintaining discipline." 101 In the category of dress and appearance, the study looked first toward the military interest. It was determined that:

Contemporary research in the social and behavioral sciences supports what institutions have recognized for centuries: dress and appearance define who we are and what we are to ourselves and to others. Within the military such identification contributes significantly to building discipline, individual morale, unit cohesion, and service esprit de corps. . . . It is "a way of converting individuals . . . into members of a . . group." (Laird) Uniformity not only directly imposes the discipline of the group, but, more subtly, instills the self-discipline necessary for the military member to perform effectively. ${ }^{102}$

The study group then looked toward the importance of recognizing an individual's religious tenets, and concluded that the military had the responsibility to meet these needs when possible. The study group recommended that non-visible items of apparel, when they do not constitute health or safety hazards, should be permitted. ${ }^{103}$

After the study, and while the Goldman case was working its way through the courts, the Department of Defense promulgated a regulation allowing various religious practices by service members (including the wearing of a skullcap)-unless military necessity dictated otherwise. ${ }^{104}$ The National Defense Authorization Act for Fiscal Years 1988 and 1989 provides that members of the armed forces may wear items of religious apparel while in uniform, except where the Secretary of Defense determines that donning such apparel would interfere with the performance of military duties, or where the apparel

100. Id. at 531.

101. Joint Service Study on Religious Matters, March 1985.

102. Id. at § III, $\mathrm{B}(1), 4$.

103. Id. at \& III, C, 18-19.

104. Department of Defense Directive No. 1300.17, Accommodation of Religious Practices Within the Military Services (1985), canceled by Department of Defense Directive No. 1300.17, Accommodation of Religious Practices Within the Military Services (1988). See also, Sullivan, The Congressional Response to Goldman v. Weinberger, 121 MiL. L. REV. 125 (1988). 
was not neat and conservative. ${ }^{105}$ For example, some religious dress or grooming requirements would violate safety standards: beards may interfere with the proper fit of a gas mask; aircraft engines may suck in loose clothing; and jewelry and loose clothing may be caught in electrical equipment. ${ }^{106}$ The courts still need a way by which to judge future free-exercise claims in the military.

The general practice of the United States military, not to make exemptions for service members based on their religious beliefs, ${ }^{107}$ is derived from British practice. As Duke Wellington stated: "If an officer or any other member of the army is to be allowed to get rid of the discharge of a disagreeable duty upon such a plea, there is an end to all discipline in the army." 108

Congress took the first step in abandoning this narrow regard for service members' free-exercise rights. The military should follow the statutory guidelines; review by the courts should be based solely upon whether the guidelines were applied properly. There should no longer be any concern regarding the appropriate levels of scrutiny to apply.

\section{B. Religious Services and Holidays}

Outside of the military context, the Supreme Court has rendered a number of conflicting judgments regarding accommodation for religious services and holidays. In the early 1960s, the Court upheld various "blue laws" which required businesses to close on Sunday, even though that is a predominantly Christian day of worship. ${ }^{109}$ Requests by Orthodox Jews and other Sabbatarians for equal treatment have been deemed less important than the government's asserted interest in a uniform day of rest. ${ }^{110}$ But the Court has also held that states may not force citizens to choose between observing their day of religious worship and remaining eligible for unemployment compensation. ${ }^{111}$ And a similar conclusion was reached in a case involving religious objection to manufacturing of armaments. ${ }^{112}$

105. National Defense Authorization Act for Fiscal Year 1988 and 1989, Pub. L. No. 100$180, \S 508,101$ Stat. 1019, 1086-87 (codified at 10 U.S.C. § 774 (1988).

106. JOINT SERVICE STUDY, supra note 101, at $\S$ III, B(1), 7-8.

107. Folk, supra note 27, at 61 .

108. W. Winthrop, Winthrop's Military LaW and Precedents 576 (2d ed. 1920 reprint).

109. McGowan v. Maryland, 366 U.S. 420 (1961); Two Guys v. McGinley, 366 U.S. 582 (1961).

110. Braunfeld v. Brown, 366 U.S. 599 (1961).

111. Sherbert, 374 U.S. 398.

112. Thomas, 450 U.S. 707. 
The armed forces' interest focuses on two intertwined considerations: (a) the effects on morale of accommodating ritual requirements of individual service members as well as esprit de corps, and (b) the impact on military effectiveness. ${ }^{113}$ Currently, the normal peacetime work week allows the great majority of American service members to participate in the religious services of their choosing. ${ }^{114}$

But the military might not always be able to meet an individual's worship needs. The Joint Service Study on Religious Matters led to a change in Army Regulation 600-21, and set forth five factors in determining whether to grant sincere requests for accommodation of religious practices. Under these rules, commanders should consider the following: (a) the importance of military requirements in terms of individual and unit readiness, health and safety, discipline, morale, and cohesion; (b) the religious importance of the accommodation to the individual; (c) the cumulative impact of repeated accommodations of a similar nature; (d) alternative means available to meet the requested accommodation; and (e) previous treatment of the same or similar requests, including treatment of similar requests made for other than religious reasons. ${ }^{115}$

These guidelines are not absolute and the military will probably continue to face conflicts between individual free exercise of religion and military requirements. However, because of the increased emphasis on a case-by-case basis, decisions of the commanders will have a higher probability of surviving judicial review.

\section{Dietary Laws}

Various religions adhere to strict dietary requirements. For example, certain Christian groups as well as Jews and Muslims prohibit the eating of pork. Numerous faiths limit eating to specific hours, days, nights, or other periods of time (such as a group of days or even weeks). ${ }^{116}$ Such restrictions present a problem to those who keep strictly kosher, are vegetarians, or have other religious dietary requirements. The primary interest the military services have in service members' diets stems from the obvious relationship between diet and health and, thus, an individual's ability to perform his assigned

113. JOINT SERVICE STUDY, supra note 101, at $\S$ II, B(1), 4.

114. Id.

115. Dept. of Army, Reg. No. 600-20, Personnel-General-Army Command Policy \& Procedures (Aug. 26, 1985).

116. E.g.: fasting on Good Friday (Christian), Yom Kippur (Jewish), or Ramadan (Moslem); others include vegetarians. 
task. ${ }^{117}$

Additionally, the military has to maintain a dining service that is both efficient and cost effective, as well as one capable of adjusting quickly from peacetime to wartime conditions. On the one hand, if special diet circumstances are not accommodated the service members might not receive adequate nutrition and individual performance may very well decrease. On the other hand, however, if the military met all religious dietary tenets, a heavier financial and administrative burden would be incurred. ${ }^{118}$

In this context the armed forces can be analogized to a prison system. Both have a strong interest in maintaining internal discipline through regimentation and uniformity. The Supreme Court in dealing with prison cases has declared that prisoners do not leave their Constitutional rights at the prison gate. ${ }^{119}$ In Cruz v. Beto, ${ }^{120}$ the Court established the requirement that prison authorities ensure all prisoners a reasonable opportunity to practice their religion freely. ${ }^{121}$ In Kanane v. Carison, ${ }^{122}$ the Second Circuit upheld a Jewish prisoner's right to a kosher diet, requiring the government to demonstrate that refusal to serve kosher food to Orthodox Jewish prisoners was the least-restrictive means of achieving. a substantial penal goal; the fact that such accommodation presented minor difficulties for other prisoners was not substantial enough to justify denying kosher food to Orthodox Jewish prisoners. ${ }^{123}$ However, in United States v. Huss, ${ }^{124}$ a New York court upheld the prison's denial of kosher food to Jewish prisoners because the denial was reasonably related to the prison's interest in keeping down costs and affording all prisoners equal treatment. Thus, courts have utilized both a strict-scrutiny test and a rational basis test in dietary cases-with opposite results.

Several federal cases involving prisoners' religious rights have

117. JoINT SERVICE STUDY, supra note 101, at § IV, B(1), 5 .

118. Id at 5-6 (for example, additional messsing facilities might be needed, food service personnel would require additional training in food preparation and handling, increased time in preparation, in some cases, (i.e. preparation of kosher food) participation of rabbis or other non-military religious leaders.).

119. See, e.g., Pell v. Procuneer, 417 U.S. 817, 822 (1974) (stating that prisoner's retention of first amendment rights is not inconsistent with his status or objectives of correction system); see also Note, Goldman v. Secretary of Defense, Restricting the Religious Rights of Military Servicemembers, 34 AM. U. L. REV. 881, 891 (1985).

120. 405 U.S. 319 (1972).

121. Id. at 322 (stating that first and fourth amendments guarantee prisoner's right to exercise their religion freely without fear of penalty.)

122. 527 F.2d 492 (2nd Cir. 1975).

123. Id. at $495-96$.

124. 394 F.Supp. 752 (S.D.N.Y. 1975). 
been decided subsequent to Smith. One in particular, Hunafa v. Murphy, ${ }^{125}$ suggested that an inmate's first amendment claim to a porkfree diet might not survive application of the new Smith standard.

Again, the Joint Service Study had various recommendations for accommodating dietary restrictions of military service members. It was determined that to the extent the military can provide meals for individuals with dietary restrictions (especially where this can be done without the appearance of special or favored treatment), there would be a positive impact on morale. ${ }^{126}$ The Study recommends first that the military continue to work to meet the dietary and nutritional needs of service members, as well as address their variety of tastes. ${ }^{127}$ Where separate rations are a possible alternative, it recommends that the military include religious reasons as a factor to be considered in granting allowances. Although special demands of field and sea conditions impose constraints on both the military and on the individual, where feasible the military should continue to allow its personnel to give out food rations when military conditions permit (or allow service members to prepare their own special meals). ${ }^{128}$ In addition, the military should consider the feasibility of developing combat rations that can be used universally and which also meet the dietary restrictions of as many service members as possible. ${ }^{129}$

\section{Medical Treatment}

Can military personnel refuse medical treatment because of their religious beliefs? If they are sincere, then the Constitutional question is whether their own physical well-being or that of their comrades-inarms justifies infringement of their free exercise rights. ${ }^{130}$ Both the military and civilian precedents have consistently held that inoculations and medical treatment for various injuries can be administered over the objections of the patient-whether such objections are based on religious or other grounds. ${ }^{131}$ The military must be concerned with both the physical and spiritual well-being of its service members,

125. 907 F.2d 46 (7th Cir. 1990). See also Friend v. Kolodzieczak, 923 F.2d 126 (9th Cir. 1991)(prisoners denied possession of rosaries and scapulars in their cells). Cf. Salaam v. Lockhart, 905 F.2d 1168 (8th Cir. 1990)("Smith does not alter the rights of prisoners; it simply brings the free exercise rights of private citizens closer to those of prisoners.").

126. JoINT SERVICE STUdY, supra note $101, \S \mathrm{IV}, \mathrm{C}, 8$.

127. Id.

128. Id

129. Id. Note, however, that most religions allow dispensations in cases of extreme hardship, and some (e.g., Judaism) require violation of the dietary laws in order to save life or limb.

130. Foreman, Religion, Conscience and Military Discipline, 52 MIL. L. REV. 77, 84 (1971).

131. Zucht v. King, 260 U.S. 174 (1922); Jacobsen v. Massachusetts, 197 U.S. 11 (1905). 
and with the efficient use of its medical systems. ${ }^{132}$

Current military practice allows exemption from routine inoculations in peacetime situations. ${ }^{133}$ These decisions are on a case-by-case basis; exemptions are not permanent. For example, exemptions have been granted from having to receive flu shots because of the reduced chance of getting ill in situations where most others have been inoculated, and in view of the fact that flu viruses most of the time have a limited effect. On the other hand, the military is reluctant to grant permanent exemptions from immunizations since military forces frequently leave the confines of the United States, and service members without inoculations have historically contracted a wide variety of diseases. The current practice is that if one has a medical exemption for inoculations but is being assigned to a location that requires specific immunization, the individual is required to receive the inoculation or will not be assigned to that location. ${ }^{134}$

The question remains: Can the military permit individuals with sincere religious beliefs the right to refuse medical treatment? The answer is probably "no." Not only would there be an increased legal and moral burden on the military's medical services, but also a potential for a service member to be away from duty for extended periods of time. Furthermore, there is a possibility of spreading disease to others and a limitation in the amount of assignments. In wartime, especially, it is important to be able to gather manpower in maximum numbers. In contrast, in peacetime situations, it might be possible to continue the current practice of allowing certain exemptions on a case-by-case basis.

It was recommended by the Joint Service Study that the military continue its case-by-case immunization practices, but only when it would not adversely affect a service member's health or interfere with his/her ability to carry out the appropriate duties. ${ }^{135}$ In order that there be consistent treatment among religious groups desiring these medical exemptions, a clearer set of guidelines or regulations should be promulgated.

\section{E. Military Chaplaincy}

The creation of the military chaplaincy by Congress is consistent with a tradition that began prior to the adoption of the Constitu-

132. Army Reg. No. $600-20$, ch. 5 (Oct. 15, 1980).

133. Id.

134. JoINT SERVICE STUdy, supra note 101, § V, A(2), 5.

135. Id. 
tion. ${ }^{136}$ When the Continental Army was formed those chaplains associated with the militia of the thirteen colonies became part of the country's first national army. ${ }^{137}$ When the Constitution was adopted (and even prior to the ratification of the first amendment), Congress authorized the appointment of a commissioned Army chaplain. ${ }^{138}$ In establishing the Army (Article I, Section 8), Congress required that it consist of all persons "necessary to form the basis for a complete and immediate mobilization for the national defense in case of emergency."139 Authorization was provided for the creation of a Chief of Chaplains, and for commissioned and other officers to be appointed as chaplains. ${ }^{140}$

Today, the primary function of the military chaplain is to engage in activities designed to meet the religious needs of a "pluralistic military community, including military personnel and their dependents." 141 In response to an increased desire for religious accommodation, the chaplains provide a myriad of services such as conducting religious services, furnishing religious education, and counseling service members. ${ }^{142}$

It also appears that the free exercise clause compels Congress to make religion available to service members who have been moved by the Army to areas where religion of their own denomination is unavailable to them. ${ }^{143}$

\section{F. The Practice Elsewhere}

There are various differences between other countries and the United States in terms of religious freedom in the military, but the premise remains the same: accommodation is allowed if it does not adversely affect the national defense. In the British Empire, for example, Sikh and Gurkha forces in India (established during the colonial period) had to be distinguished from the British troops. ${ }^{144}$ Today both groups are still part of the British military and still are allowed uniform deviations. Sikhs are permitted to wear turbans and to keep their hair long, if they choose. A similar policy also exists in Canada,

136. Katcoff v. Marsh, 755 F.2d 223, 225 (1985).

137. I P. Thompson, The United States Army Chaplaincy xix (1978).

138. Act of March 2, 1791, ch. XXVIII, § 5, 1 Stat. 222 (1791).

139. 10 U.S.C. $\$ 3702$.

140. 10 U.S.C. $\$ 3703$.

141. Katcoff, 755 F.2d at 226.

142. Id. at 228.

143. U.S. CONST. amend. 1.

144. JoINT Service StUdY, supra note 101, § III, C, 19. 
New Zealand and India, where Sikh and Jewish soldiers are permitted to wear religious artifacts with other standard items of clothing. ${ }^{145}$

The Israeli Defense forces have many service members who go into battle wearing skullcaps. After successes in four separate wars, it is hard to argue that the yarmulke has in any way interfered with their ability to wage successful war. ${ }^{146}$ In fact, Jewish military personnel wear a variety of head coverings, beards, and apparel which have religious significance. ${ }^{147}$ It has been pointed out that the Israeli experience runs counter to American military purposes of "unity and cohesion." In contrast to the U.S. military are the small size of the Israeli Defense Forces, the length of time individuals are assigned to units and, most importantly, the more immediate threat to national survival. ${ }^{148}$

Today, the United States is more like Israel and other countries in allowing religious items of apparel where the clothing does not interfere with safety or specific military duties. The degree of uniformity as well as the style of uniforms of national military forces depend on a variety of factors, including historical experience, cultural traditions and environment. ${ }^{149}$

In a wartime context, however, rules are altogether differentespecially in view of the fact that enemies seek to take advantage of the religious customs and practices of their adversaries. For example, on December 7, 1941, Japan attacked Pearl Harbor anticipating that the church-going military would be less able to respond to its attack on Sunday. Similarly, the Arab nations invaded Israel on Yom Kippur in 1973 believing that the Israeli military would not be able to function on the holiest of Jewish holidays. If its service members had not been subjected to some degree of military discipline, neither of these nations would likely have been able to respond as well as they did.

The theory in the United States is that service members do not have the same "autonomy as there is in the larger civilian community." 150 But in England "a person does not by enlisting or by entering in the air force thereby cease to be a citizen, so far as to deprive him of his rights or exempt him from his liabilities under the law."151

145. 132 Cong. REC. S10698 (daily ed. Aug. 7, 1986)(statement of Sen. Lautenberg).

146. Id.

147. JoINT SERvice STUdy, supra note 101, § III, C, 20.

148. Id.

149. Id.

150. Parker, 417 U.S. at 751.

151. 41 Halsbury's Laws of ENGLaND para 3 (4th ed. 1983). 
Although Great Britain has no document that constitutes the equivalent of the Constitution, a myriad of distinctive rights and accompanying remedies have been developed through the common law and by express statutory enactment. ${ }^{152}$

In the United Kingdom, freedom of religion encompasses freedom of worship and expression, as well as the freedom to conduct one's life in harmony with one's religious beliefs-although the status of the Church of England as the established church evidences some preference in the law for it over all other denominations. ${ }^{153}$ Religious toleration has come to the point where almost all of the impediments previously suffered by dissenters have been removed. ${ }^{154}$ For example, the Liberty of Religious Worship Act (1855) was enacted in order to secure religious freedom for Roman Catholics, Protestants and Jews in respect to places for religious worship. ${ }^{155}$ It appears that the only limitation upon the scope given to all religious bodies is that provided by the criminal law of the land. ${ }^{156}$

The armed forces in Great Britain are subordinate to Parliament. ${ }^{157}$ Authority for their existence derives from the royal prerogative: in 1661 Parliament declared that "the sole supreme government, command and disposition of the militia and of all forces by sea and land is, and by the laws of England . . . the right of the Crown."158

It was the custom of Parliament every year to pass a Mutiny Act, which limited the authority of the Crown to maintain the armed forces for a fixed period of time. ${ }^{159}$ These collections of rules evolved and remained in force until 1955, when the Army and Air Force Annual Acts were created. ${ }^{160}$

Presently, Royal Navy and Air Force personnel are treated alike in that they are governed by a statute, providing a disciplinary code, which continues for one year. They may be renewed by her Majesty through an Order in Council until the end of a five-year period, after which the disciplinary act will expire unless renewed by statute. ${ }^{161}$

152. S.H. BaILey, D.J. Harrid \& B.L. Jones, Civil Liberties, CaSes and Materials 2 (1980).

153. Id. at 341 .

154. Id.

155. Liberty of Religious Worship Act, 1855,18 \& 19 Vict. ch. 86 (Eng.).

156. D.C.M. YARDLEY, INTRODUCTION TO BRITISH CONSTITUTIONAL LAW 101 (1974)

157. 41 HALSBURY'S LAWS OF ENGLAND, supra note 151, at para. 1.

158. See E.C.S. WADE, Constitutional LAW 382 (1965).

159. Id. at 383 .

160. Id.

161. Armed Forces Act 1981, Eliz. II, part II, ch. 55 (Eng.). No order in council may be made under the Act to continue such Acts beyond the five year period. 
Despite legislative authority to maintain the armed forces, conscription has traditionally been regarded as an evil to be avoided. In 1939, however, the United Kingdom was forced to adopt a scheme of compulsory service. ${ }^{162}$ The National Service Armed Forces Act of 1939 made all males liable for compulsory service, subject to exemption for "conscientious objectors and regular ministers between the ages of 18 and 41."163 Authorization for conscription ceased in 1960, but like earlier legislation, special provisions continued for conscientious objectors to military service. ${ }^{164}$

The regulations which govern the uniform and dress of the Royal Navy are set forth in B.R. 81, Royal Navy and Royal Marines Uniform Regulations. These are the Queen's Regulations for the Royal Navy, which are not made by statutory instrument and are thus considered subordinate to all other legislation governing the Royal Navy.

The policy of the United Kingdom is not to provide any exceptions to their regulations based on race, religion or creed. ${ }^{165}$ Article $1101(1)^{166}$ sets forth the general rule that the prescribed uniforms shall be worn as specified, and that such patterns should be adhered to strictly. The Uniforms Act of $1894^{167}$ was enacted to regulate and restrict the wearing of Naval and Military Uniforms. Section 2 of that Act makes it unlawful for "any person not serving in Her Majesty's Military Forces to wear without Her Majesty's permission the uniform of any of those forces . . ."168

Article 1105 (Growth of Hair) permits all men to wear beards and moustaches after obtaining permission, but requires them to be neatly cut and trimmed and, so far as is practicable, uniformity in length is to be established. ${ }^{169}$

Article 1107 (Wear of plain clothes by ratings) creates a privilege for those leaving naval facilities to wear plain clothes. No visible items of the service uniform may be worn in plain clothes except raincoats, scarves, shoes, socks, shirts, collars, ties and windproof working jackets. More specifically, the wearing of headgear is optional. ${ }^{170}$ The regulation is vague as to whether the option relates only to off-

162. E.S.C. WADE, supra note 158 , at 389.

163. Id.

164. Id. at 390.

165. 41 HALSBURY'S LAWS OF ENGLAND, supra note 151, at para. 4.

166. Queen's Regulations for the Royal Navy 1967, ch. 11, \$1. art. 1101.

167. Uniforms Act, 1894, 57 \& 58 Vict. ch. 45, \& 2 (Eng.).

168. Id.

169. Queen's Regulations for the Royal Navy, ch. 11, §1, art. 1105.

170. Queen's Regulations for the Royal Navy, ch. 11, § 1, art. 1107. 
duty periods. Under the Motor-Cycle Crash-Helmets (Religions Exemption) Act $1976,{ }^{171}$ the Secretary of State may make regulations requiring persons driving or riding on motor cycles to wear protective headgear. Section 2 of this Act states that a "requirement imposed by regulations under this section shall not apply to any follower of the Sikh religion while he is wearing a turban." ${ }^{172}$ Most Sikh Service members are in the Royal Navy. ${ }^{173}$

In Great Britain the policy concerning religious services in the armed forces is governed largely by a Queen's Regulation, which declares that the "reverent observance of religion . . . is of the highest importance. It is the duty of all concerned to make adequate provision for the spiritual and moral needs of all personnel." 174 In addition, commanding officers "are to encourage religious observance by those under their command and are themselves to set a good example in this respect." 175 Finally, "no one is to be compelled to attend divine service against his wishes." 176

In England religious practice is governed by the same regulation which covers religious services. ${ }^{177}$ In addition, "sympathetic consideration is to be given to the needs of officially recognized religious minorities who do not profess the Christian faith."178

The medical needs of religious minorities in the British services are governed by the same general regulation which covers other concerns, treated earlier in this article. ${ }^{179}$

In Great Britain there are chaplains of the major faiths serving the armed forces, including the Royal Navy, the Regular Army, the Territorial Army Volunteer Reserve, the Royal Air Force, and other institutions. ${ }^{180}$ The duties and powers for chaplains in the Royal Navy are set forth in the Queen's Regulations for the Royal Navy (1967). The Chaplain of the Fleet is granted the ecclesiastical dignity of archdeacon, under the Archbishop of Canterbury, while holding office. ${ }^{181}$ The duties of the Army and Air Force chaplains are set

171. 38 Halsbury's Statutes of England, Road Traffic Act 1988, para. 16.

172. Id.

173. Sikhs are employed to work on Stone Cutter's Island for the Army, located in Victoria Harbor off the coast of Hong Kong.

174. Queen's Regulations for the Army J5.262 (1975).

175. Id. at J5.263.

176. Id. at $\mathrm{J} 5.264$.

177. Id. at J5.268.

178. Id. at $\mathrm{J} 5.264$.

179. Queen's Regulations for the Army (1975).

180. 14 HALSBURY'S LAwS OF ENGLAND para. 727 (4th ed. 1974).

181. Queen's Regulations for the Royal Navy at 44. 
forth in the Queen's Regulations for the Army ${ }^{182}$ and in the Queen's Regulations for the Royal Air Force. ${ }^{183}$ The Army chaplains are under the supervision of the Chaplain General to the Forces. ${ }^{184}$ Those Air Force Chaplains who belong to the Church of England are under the control of the Chaplain-in-Chief. Both the Chaplain General and the Chaplain-in-Chief, like the Chaplain of the Fleet, hold the position of archdeacon under the Archbishop of Canterbury. In addition there is a Jewish chaplain, as well as Roman Catholic chaplains.

\section{CONCLUSION}

A review of Supreme Court jurisprudence indicates that the military has little guidance for an appropriate standard of review when deciding various religion-based exemptions in military settings. Congress has taken the first step by setting forth regulations which the military can implement on a case-by-case basis (especially that regarding religious apparel). The Joint Service Study went into an explicit analysis by detailing religious practices and their potential impact on the military interest. Consequently, its recommendations were soundly based.

Congress should continue to act on the Joint Service Study's recommendations by formulating guidelines to which military personnel can refer in order to analyze each potential conflicting situation regarding service members' free exercise of religion rights. This would include guidance in dealing with religious holidays, dietary restrictions, and medical treatment. Not every situation will fit neatly into specific categories: a case-by-case analysis which follows these guidelines and weighs the competing interests is needed. The courts can thereby avoid getting involved in "military issues," deciding instead whether the congressional guidelines have been properly followed.

Although it is difficult to compare American military practices with those of other countries in order to perhaps come up with a "better" system-because of the many historical, cultural, and religious differences involved-such comparisons illustrate the relatively liberal regulations in the U.S. armed forces. The trend in the United States allows even more freedom to service people to practice religion fully-a trend which many hope is likely to continue. However, it is

182. Queen's Regulations for the Army J5.274 (1975).

183. Queen's Regulations for the Air Force J837 (1985).

184. 14 HALSBURY'S LAWS OF ENGLAND, supra note 180, at para. 729. 
incumbent upon Congress to step forward and offer appropriate statutory guidance.

The Supreme Court has long presumed the supremacy of the first amendment, and has often reaffirmed the very heavy burden of proof it forces the powers-that-be to overcome. Even the current Justices, who in all probability would continue paying deferential homage to the military's own definitions of "military necessity," would not likely uphold the regulations handed down during Operation Desert Storm. Even they, one hopes, would find it hard to see how chaplains setting up a plastic Christmas tree in a tent, or wearing religious insignia on their uniforms, or holding a prayer service, could possibly harm a military mission. It may be wrong to invest that much faith in this Court, but any ruling to the contrary would represent a harsh abandonment of long-held American values.

It's incumbent on all of us to keep them honest. 